\title{
Book review: Ting and I: A Memoir of Love, Courage and Devotion
}

Patricia A. Burns, RN; PhD, FAAN, Professor of Nursing, University of South Florida, Tampa, Florida, USA

Key Words: book review experiences * intensive care

ESPAÑOL
Revisión de Libro: Ting y yo: Memorias de Amor, Valor y
Devoción
Palabras clave
Cuidado intensivo, experiencias, revisión de libro

Ting and I: A Memoir of Love, Courage, and Devotion by Douglas Winslow Cooper, Ph.D

\section{REVIEW by Prof Patricia A Burns}

Dr Cooper's book "Ting and I" describes a very deep relationship between a man and woman that transcends what some would say is a 21 st century marriage. This poignant story gives the reader insight into the "soul bonding" of a man and a woman. In today's society love and marriage follows the route of boy meets girl, fall in love because of common interests, possibly similar backgrounds, equal aspirations of professional careers and family values. "Ting and I" deviate dramatically from this ethereal vision of the "perfect marriage" and present a much deeper bonding and relationship. Readers will be awed by the spiritual feeling they will experience as they assimilate the true meaning of Douglas and Ting's binding love. In contrast, the stark reality of the health care system rises to direct patient care based on "quality of life" issues. Most health care professional are focused on obtaining health care proxies, and living will declarations. These approaches inevitably lead to the establishment of "Do not resuscitate" order in the medical record. Ting and Douglas have struggled with this mentality throughout the book and describe instances where medical personnel assumed that because of her disabling condition no lifesaving procedures are to be instituted. Struggles like those Douglas and Ting have overcome are very difficult for the "day to day mindset "of the health care professional to understand and or support.

This book reads like the book Love Story, but with the harsh realities of how a couple deals with a catastrophic illness. Catastrophic illness is a taboo in our modern 21st society. It is something that "happens to others not me". Yet, it happens all too frequently, and this story walks us through the "day to day" challenges of two kindred spirits intimately experiencing the dilemma.

"Ting and I" is a must-read for any health care professional. It presents the opposite side of what constitutes quality of life as described in medical and nursing textbooks. An "eye-opening" revelation into a symbiotic loving relationship in face of huge obstacles.
FOREWORD by Dr Richard F Walker MD, FCCP

Doug Cooper's homage to his wife, presented as a 67th birthday gift, is a story about the power of love to overcome cultural taboos, through persistence and patience, and to triumph over a near-fatal illness and daunting physical disability. It is also a celebration of optimism over despair by two people passionately committed to each other "for better or worse, in good times and bad, in sickness and in health."

This tribute from husband to wife will remind those who read it of the "better angels of our nature," as it inspired this physician who was fortunate to have shared a brief moment of their lives.

Tina entered the critical care unit of Orange Regional Medical Center because of a catastrophic illness. I was part of the intensivist team providing her care through her 100-day hospital ordeal. Probably because Tina, Doug and I grew up in New York, shared common experiences and social values, are of the same age, and went to rival colleges in the same years, we developed a natural rapport. As I have been accorded in the book a disproportionate credit for Tina's survival, I must state that our ultimate success resulted from the efforts of the entire health care team and, in no small measure, the efforts of Doug and Tina themselves.

Intensive care specialists have learned to cope with the possibility of bad outcomes, in part, by depersonalizing the patient into a series of physiologic challenges, much like the combat soldier might resist making very close friends when the chance of death is ever-present. The battle for life then consists of attempts by the medical staff to raise blood oxygen, combat infection, preserve nutrition and urinary output and avoid hospital-acquired infection.

There is also the danger than the physician can partially replace the patient as the object of care by worrying about the frequency of reportable iatrogenic complications, medico-legal risks and reimbursement considerations.

Dr Jerome Groopman, in his excellent book, How Doctors Think, describes the biases and decision-making consequences of such distractions, as well as the dangers of projecting one's concept of meaningful existence on others. He specifically singles out the important role of the patient or patient advocate in re-focusing the physician to address what is objectively possible and beneficial.

Such a bias crept into my own thinking as my mounting feelings of hopelessness at returning Tina to a level of function worthy of the effort were rejected by Doug. His exhortations for better care were often viewed by me as selfishly motivated and without sufficient regard for the burden and suffering the illness was creating for Tina. My attempts to gauge her feelings during Doug's infrequent absences from her bedside revealed that her goals mirrored his. I attributed her attitude to a desire not to hurt or disappoint him, or to stereotypical Asian stoicism. 
Doug tirelessly directed the attention of the health care team to seemingly trivial aspects of her care, asking detailed questions and demanding satisfactory answers, even occasionally suggesting changes in her care plan. My periodic annoyance, hopefully not always apparent, served to refocus my attention away from the pathophysiology and back to Tina. What I did not initially realize was that Doug's persistence was improving his wife's care. I began to marvel at the tenderness he lavished on Tina that both sustained her morale and dispelled all lesser explanations I might have conjured up to explain the dynamics of their relationship.

Eventually, Tina left the hospital and went home to a cocoon of nurses, catheters, and ventilators, and I saw her several times a year in my office. Their mutual affection seemed to grow stronger with time and was uplifting to watch, given the relentless burdens Tina's illness imposed on both of them.

Doug dedicates this book to Tina, his "good soldier," but in a larger sense it is also a tribute to his powerful advocacy for her survival. I believe their love saved them both.

My participation in Tina's care made me a better physician and provided me with one of the most rewarding experiences of my professional career.

I want to thank you both, Tina and Doug, and wish you continued years of happiness and joy together. 